\title{
Mobile Classroom for Military Tactical Training in Cavalry Mission Planning
}

Sala móvil para entrenamiento táctico militar en planificación de misiones de caballería

Sala móvel para o treinamento tático militar no planejamento de missões de cavalaria

\section{Daniel Eduardo Rojas-Ballesteros ${ }^{1}$ César Augusto Molina-Saldarriaga ${ }^{2}$ Cristie Palomo-Navarro ${ }^{3}$}

Received: May $17^{\text {th }}, 2019$

Accepted: August 5 ${ }^{\text {th }}, 2019$ Available: September $16^{\text {th }}, 2019$

How to cite this article: D. E. Rojas-Ballesteros, C.A. Molina-Saldarriaga, and C. Palomo-Navarro, "Mobile Classroom for Military Tactical Training in Cavalry Mission Planning," Revista Ingeniería Solidaria, vol. 15, no. 3, 2019. doi: https://doi.org/10.16925/2357-6014.2019.03.11

Artículo de investigación. https://doi.org/10.16925/2357-6014.2019.03.11

1 Escuela de Caballería del Ejército de Colombia ORCID: https://orcid.org/0000-0003-4560-3481

E-mail: daniel.rojasba@buzonejercito.mil.co

2 Escuela de Caballería del Ejército de Colombia ORCID: https://orcid.org/0000-0003-1940-5289

3 Escuela de Caballería del Ejército de Colombia ORCID: https://orcid.org/0000-0001-5616-2605 


\begin{abstract}
Introduction: This article is the result of the research project entitled "Mobile classroom for military tactical training in cavalry mission planning, development in the Cavalry school of the Colombian Army from 2010 to 2017 ". Its purpose is to identify tools to improve the training process of military personnel.
\end{abstract}

Problem: The training is carried out in a theoretical environment as there is currently no alternative means to training personnel in this field. The present investigation aims to improve the instruction of the army personal with their varying roles and ranks -officers, non-commissioned officers (NCOs) and enlisted soldiers-, when encountering individual and collective training.

Objective: Evaluate the impact of the implementation of a mobile classroom equipped with simulation tools, as a strategy for the formation of the members of the Cavalry School.

Methodology: Empirical study developed in 5 stages: (i) initial instruction, (ii) diagnostic test, (iii) diagnostic feedback, (iv) performance test and (v) performance evaluation. For this, the adaptation of a trailer, such as a mobile classroom, and the ARMA 3 game was used.

Results: The use of the mobile classroom allowed for an increase in the number of trained people whilst reduced training times resulting in lower operating costs and greater sustainability.

Conclusion: The implementation of the mobile classroom and the simulation system contributed to the development of skills and abilities, improved decision-making capacities, increased perceptual variation and improved coordination, communication and team decision-making.

Originality: First mobile classroom for military training, with invention patent, 10-61804.

Limitation: The investigation was carried out at the Cavalry School. The results can only be replicable in other military study centers.

Keywords: Planning, training, instruction, doctrine, simulation, military tactical y cavalry.

\title{
Resumen
}

Introducción: El presente artículo es resultado del Proyecto de investigación titulado: Sistema Portátil de Simulación Para Vehículos Militares Para el Entrenamiento Táctico, Desarrollo por la Escuela de Caballería, Ejército de Colombia del 2010 al 2017, tiene como propósito identificar herramientas para mejorar el proceso formativo del personal militar.

Problema: El entrenamiento se realiza en un ambiente teórico, no se cuenta con un medio eficaz para entrenar al personal en la toma de decisiones. A efectos de permitir la instrucción de las funciones y competencias -oficiales, suboficiales y soldados- que genere un entrenamiento individual y colectivo.

Objetivo: Evaluar el impacto de la implementación de un aula móvil prevista con herramientas de simulación, como estrategia para la formación de los miembros de la Escuela de Caballería.

Metodología: Studio empírico desarrollado en 5 etapas: (i) instrucción inicial, (ii) prueba de diagnóstico, (iii) retroalimentación del diagnóstico, (iv) prueba de desempeño y (v) evaluación de desempeño. Para ello se dispuso de la adecuación de un tráiler, como aula móvil, y se usó el juego ARMA 3.

Resultados: El uso del aula móvil permitió aumentar el número de personas capacitadas, disminuir los tiempos de capacitación, significó menos costos operativos y mayor sostenibilidad.

Conclusión: La implementación del aula móvil y el sistema de simulación contribuyó al desarrollo de competencias y habilidades, mejoró las capacidades para la toma de decisiones, aumentó la variación perceptiva y mejoró la coordinación, comunicación y toma de decisiones en equipo.

Originalidad: primera aula móvil para entrenamiento militar, con patente de invención 10-61804, 
Limitación: la investigación se llevo a cabo en la Escuela de Caballería. Sus resultados solo pueden ser replicables en otros centros de estudios Militares.

Palabras claves: planeamiento, formación, instrucción, doctrina, simulación, militar, táctica, caballería.

\section{Resumo}

Introdução: o presente artigo é resultado do projeto de pesquisa intitulado "Sistema portátil de simulação para veículos militares para treinamento tático", desenvolvido pela Escola de Cavalaria, Exército da Colômbia, de 2010 a 2017, que tem como propósito identificar ferramentas para melhorar o processo de formação dos militares.

Problema: o treinamento é realizado em um ambiente teórico, não há um meio eficaz para treinar o pessoal na tomada de decisões. Para permitir a instrução das funções e competências - oficiais, suboficiais e soldados - que gere um treinamento individual e coletivo.

Objetivo: avaliar o impacto da implementação de uma sala móvel preparada com ferramentas de simulação, como estratégia para a formação dos membros da Escola de Cavalaria.

Metodologia: estudo empírico em cinco etapas - (i) instrução inicial, (ii) prova de diagnóstico, (iii) feedback do diagnóstico, (iv) prova de desempenho e (v) avaliação de desempenho. Para isso, contou-se com a adequação de um trailer, como sala móvel, e usou-se o jogo ARMA 3.

Resultados: o uso da sala móvel permitiu aumentar o número de pessoas capacitadas, diminuir os tempos de capacitação, além de significar menos custos operacionais e maior sustentabilidade.

Conclusão: a implementação da sala móvel e do sistema de simulação contribuiu para o desenvolvimento de competências e habilidades, melhorou as capacidades para tomar decisões, aumentou a variação perceptiva e melhorou a coordenação, a comunicação e a tomada de decisões em equipe.

Originalidade: primeira sala móvel para treinamento militar, com patente de invenção 10-61804.

Limitação: a pesquisa foi realizada na Escola de Cavalaria. Seus resultados somente podem ser replicáveis em outros centros de estudos militares.

Palavras-chave: planejamento, formação, instrução, doutrina, simulação, militar, tática, cavalaria.

\section{INTRODUCTION}

Cavalry Mission Planning provides the Commander with the perspective he needs to function in the right moment and place, as well as the size and current composition of the mechanized platoon (groups of men in different military vehicles), his exact device (armament), where it is strong or weak and when a correct application of superior combat power can have a decisive effect. The Cavalry, in that sense, indicates to the Commander the route for the mobilization of the force that guarantees an uninterrupted advance towards the objective, in spite of the conditions of the terrain. The commander guides the units in offensive maneuvers towards the enemy and indicates the strategy before the routes and critical points without leaving aside the continuous monitoring of his units and the enemy [1] 
The Planning of Cavalry Missions has great relevance in the education of each member in the knowledge and use of the weapon, since it forms the bases for the procedures, the team work and the decision making for the protection of border areas in defense of national sovereignty. In order to achieve these objectives, specific training is required to develop the skills of the personnel and enhance their military activity, perfecting their functions within the Mission according to their profile: platoon commander (officer), vehicle commander, vehicle operator and gunner. These roles must be trained so that they can coordinate and fulfill the established plans according to the Mission by making assertive decisions before any threat presented by the enemy. During the training it is necessary to let the commanders at different levels of command know the correct use of these units in support of military operations and those of combined weapons. The platoon commander is responsible for the decisions that affect the personnel under his command and the behavior of his subordinates, following the intention of the squadron commander in fulfillment of the mission. In addition, platoon commanders control discipline, maintenance of the vehicles -both technically and tactically-, the application of the doctrine of the cavalry platoon and must also know the capabilities and limitations of the personnel and equipment within their unit. The NCO replacing the platoon commander, applies the guidelines according to the order of the commander of the unit and assumes command in the absence of the commander. A vehicle operator must respond to the platoon commander for the correct operation and maintenance of the vehicle assigned to him [2]

This training was developed in a purely theoretical environment, aimed at the courses and specialties involved in the subject of Planning Cavalry Missions, using more time in theoretical education, and without having an effective means to train staff in tactical decision making and the tactics of war. The present investigation aims to improve the instruction of the army personal with their varying roles and ranks -officers, non-commissioned officers (NCOs) and enlisted soldiers-, when encountering individual and collective training. Its purpose is to identify tools to improve the training process. Taking into account that the possibility of making an adaptation to the characteristics of a real environment demands a high investment in resources ${ }^{4}$, an empirical research was carried out in response to the need for training, using a trailer provided by the Cavalry School as a new teaching classroom that would also have the possibility of being moved around the national territory, giving the opportunity to all staff to be instructed in the different units [3]. A focus was made on the skills

4 Physical, human and financial, referring to the space of the land, vehicles and their maintenance, movement of personnel, supplies and raw materials such as ammunition for weapons. This budget exceeded the estimate by the Cavalry School for these effects, in addition to considering costs for aspects of sustainability. 
that students should acquire according to their profile and function within the subject taught, installing maneuver and simulation equipment [4] composed of 8 interactive modules. 4 modules were installed with vehicle operators in mind -these include the relevant levers and pedals- and 4 for the gunners who require a joystick. All modules used computer equipment for interaction with the game ARMA 3 [5]; the software platform used for simulating different scenarios, with the climate or cartography required in the instruction.

In relation to the skills that must be developed within the members of the force, it is necessary for the soldiers of the cavalry to understand the other roles in the platoon (platoon commander, vehicle commander, operator and gunner) so as to better understand the reaction and behavior in situations under pressure. This establishes a profile for a cohesive crew, strengthening the powers of the commander and fulfillment of orders; all this with the criteria offered by the live experience provided by the inclusive instruction of the mobile classroom.

In the present text, the state of the art of military training -through the use of mobile classrooms and simulation interfaces, materials and methods- are described, followed by the results and conclusions of the study, culminating in some recommendations. It is intended to highlight the constant work done by the Cavalry School and the Colombian National Army to instruct its men with quality, relevance and opportunity, seeking the best tools to carry out the training according to their military profile and making use of the technology to support the doctrine taught through theory.

\section{BACKGROUND}

Studies on the use of computer technologies such as simulation and mobile classrooms for the development of training or training activities have been developed since the nineties. However, the use of this type of technology for the training of military personnel and their documentation are relatively recent. Regardless of this, there are studies on the use of mobile classrooms and simulation interfaces, and military training and the use of simulators. The study by Coman, Bârsan, and Badea [6] about these elements, based on the analysis of the simulation systems designed for the real simulation used at the NATO level, presents a possible framework focused on the management methodology based on projects to address the current problems of military education based on simulation. They conclude that it is possible to analyze, through the proposed methodological design, other types of simulation systems: from the constructive and virtual simulation category to the simulation of the game 
type. Likewise, they conclude that realistic training creates the need to use modern training mechanisms from basic military education to specialized areas.

It is in the training processes of medical personnel where greater interest has been revealed on the use of mobile classrooms and simulation technologies. Thus, Guze [7] presents how the use of technologies can provide the infrastructure and the basis to address many of the challenges in the provision of medical education for the future. In addition, Birt, Moore, \& Cowling [8] inquire into strategies for trainers with the objective of helping distance education students to practice their skills before fulfilling their residency obligation, to match their conditions with students in attendance. These studies conclude, among other things, that the use of technologies in the processes of undergraduate, postgraduate and continuing education is increasingly frequent; the use of technologies for the training of medical personnel facilitates the acquisition of knowledge, improves decision making, perceptual variation and coordination of skills. It provides an educational environment that involves the learner and allows learning that does not endanger the patient. Additionally, it allows for the assessment of skills and allows the student to access tools for continuous learning and updating [7]. However, despite the statistically significant improvements in the school performance of distance learners, some adjustment problems must be overcome with the pedagogical model. [8]

On the use of simulation for military training, there are two important studies in Spanish. Nitschke [9], argues that the complexity of current weapon systems, the wide range of missions, military operations in unknown territories, and asymmetric threats, among others, require an expansion of simulation and training methodologies. For this, technologies based on video games or computer games allow instruction in extreme scenarios and the internalization of complex procedures. He affirms that the challenge of land forces is to incorporate simulation methods into the training process of the individual combatant. Another advantage of the use of computer games is that it reduces the acquisition costs of a high-tech military simulator. This imposes challenges to the leisure industry, in relation to the development of software available for military training [9]. On the other hand, the use of the constructive simulation system COMBATER, by the Ground Operations Command (COTER) of the Brazilian Army, is reported in an exercise for the students of the first year of the Command and Staff Course (CCEM) of the Army Command and General Staff School (ECEME) [10].

Studies in the English language are more abundant. Bratt [11] took care to describe the role of simulation-based training; from interviews and observations, to military instructors in the fields of damage control and ship management. According to its conclusions, the clarity in the definition of the central area of an intelligent system 
of tutoring via simulator, must incorporate a strategy to overcome the deficiencies in the domain of peripheral knowledge. Thus, interaction with natural language, which can include the formulation of open questions to students about their performance, can help overcome these deficiencies [11]. On the other hand, in the same descriptive line, Chang, Chang, \& Chung [12] seek to determine the benefits of simulation training systems through the application of an analytical hierarchy process (AHP), the analysis of important performance (IPA), and the 2-tuple diffuse linguistic representation model. In their conclusions they affirm that when verifying the results, it is possible to demonstrate that this method calculates and analyzes, with precision, the benefits of the training simulators. Likewise, these results can be used to prioritize the simulators according to training needs, suggest criteria for the acquisition of more profitable simulators, improve the efficiency of the simulators, obtain long-term developments in the training of the force, maximize the return on investment with a limited budget, reduce training losses, improve the quality of the training, and improve the overall efficiency of the simulator. [12]

Riddle, Chapman, Pike, and Norfleet [13] illustrate the challenges of evaluation in military training and present a general description of a training assessment research orientation tool; the Medical Recovery Simulator of Medical Simulation (MST-READI). With this they seek to help develop a research protocol or evaluation of military training. Finally, in this descriptive line but in the field of health in military training, Naumann, Bowley, Midwinter, Walker, \& Pallister [14], analyze the high-fidelity simulation model of pelvic hemorrhagic trauma. Through modeling, they conclude, that the use of dynamic models for trauma simulation highlights the importance of training in non-technical skills or human factors. Thus, through role-play, the importance of teamwork, communication, the capacity for individual decision-making and general situational awareness is highlighted. In addition, its importance is highlighted by the participants, who emphasize the multidisciplinary training and the evaluation process during the simulation of high-risk scenarios. [14]

On the adoption or implementation of simulation models there are several important works. Cosma \& Stanic [15] seek to adapt and generalize analytical models and demonstrate their correct integration in military training. This would affect the methodologies and procedures for the implementation and evaluation of military capabilities and analysis of balance of forces and trends through the implementation of a software model; simulation based on specialized computer languages. With their study, they conclude that the implementation of a simulated training model allows for the evaluation of real-time strength capabilities and training in new types of missions [15]. Goolsby and Deering [16] implemented a new hybrid simulation curriculum in the 
Bushmaster Field Training Exercise of the University of Uniformed Services of Health Sciences for fourth-year medical students. The objective of the work was to determine if hybrid high-fidelity simulation could be implemented successfully in a field environment and, thus, they sought to improve the medical realism of the training, allow students to practice emergency medical combat skills in stressful field conditions, and develop the leadership of the medical team. Through low, medium and high-fidelity simulators, in combination with standardized patients, students performed their tasks and finally they were asked for comments on the training. The study concludes that it is possible to successfully implement simulators in field exercises for large-scale medical-military training, which results in a benefit for training purposes.

In this same line, Taylor and Barnett [17] evaluated the effectiveness of the training of a new simulation interface with a laptop integrated into a soldier's loading equipment. To do this, they conducted a heuristic usability evaluation accompanied by two experiments. In these, 8 evaluators interacted with both interfaces and completed a survey regarding the use. In the first experiment, the training retention of the portable interface was compared with a desktop simulator and an interactive training video. In the second experiment, the training transfer of the simulators with a real environment were compared. The results of the study show that the live training provided a superior transfer of training to the conditions of the simulator in both interfaces. Thus, it is concluded that the portable simulator tool is less efficient for transferring of training, in relation to the desktop simulator and training in a real environment.

From the reviewed studies it is possible to conclude that the implementation of strategies and technological tools in training processes, such as mobile classrooms and simulators, contributes to improving the development of competencies and skills in students and future professionals. This has been demonstrated in medical training and military training, which is of particular interest in this study. In relation to this field, the high costs and risks associated with the training of the force, added to the challenges imposed by the new weapons, the new contexts of conflict and the demand of last generation competences of the members of the force at all levels, require innovative training strategies. There, the technological developments play a very important role.

\section{MATERIALS AND METHODS}

An empirical study was carried out with the aim of improving the training process of the members of the force, in terms of quality, relevance and opportunity. The impact that the implementation of a mobile classroom, equipped with simulation interface devices for combat situations, was evaluated through the training of students who 
participated in the process. For this, it was necessary to adapt a trailer as a mobile classroom, in such a way that it could be transferred to any part of the national territory in which it would be required to develop training processes. For the design of the mobile classroom, the trailer was fitted with maneuver and simulation equipment, according Cavalry Mission Planning instructions that requires operation of vehicles, weapons and direction of the commanders to the personnel under their command, to meet the objective of neutralizing threats in border areas. For the present case, medium and heavy vehicles are simulated by the institution, particularly the ASV vehicle.

The ASV vehicle is a tactical light reconnaissance $4 \times 4$ vehicle, with the ability to travel in any terrain of the national geography, equipped with the necessary weapons to defend against a possible threat. Its crew is composed of a commander, an operator, a gunner and a number of crewmen who provide additional vehicle security.

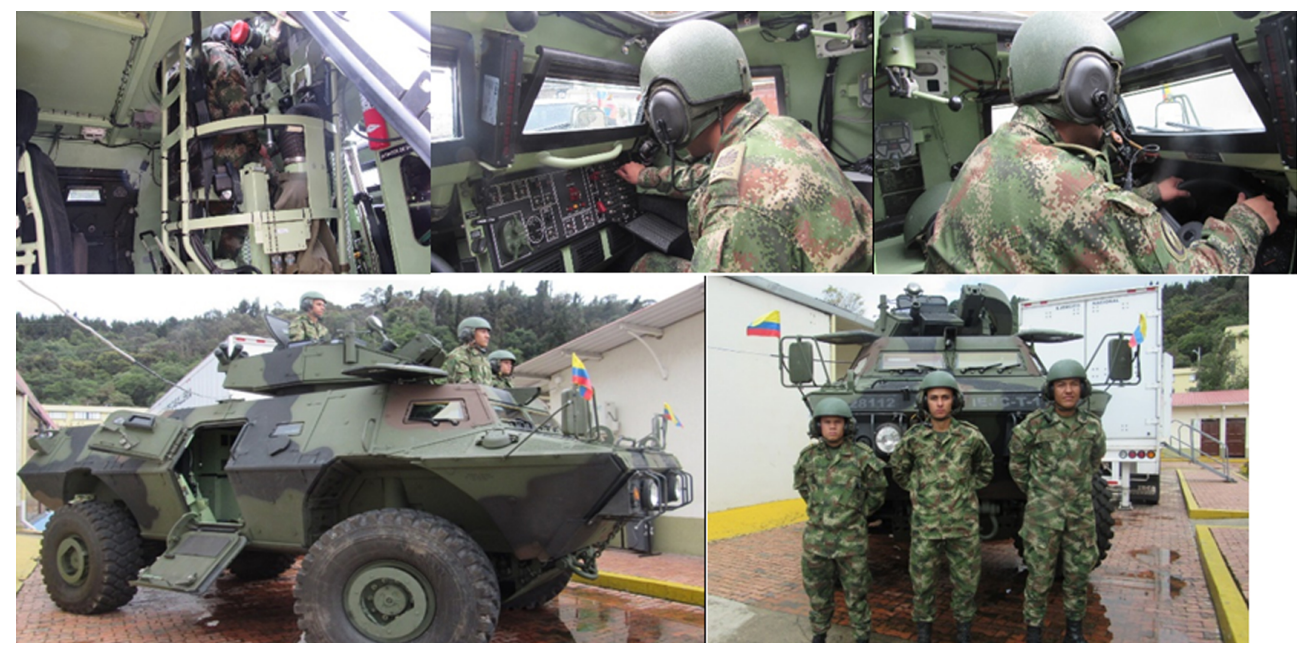

Figure 1. Interior of the ASV vehicle Source: courtesy of the Cavalry School

The maneuver and simulation equipment installed in the Mobile Classroom consists of 8 interactive modules. 4 of them are installed with vehicle operators in mind -which have levers and pedals-, and the other 4 for gunners who require a joystick. The capacity of students for this training is 13 people, which indicates that the remaining 5 have the roles of team and platoon commanders, making use of the respective computers, performing all the execution of the training with ARMA 3 [5]. 


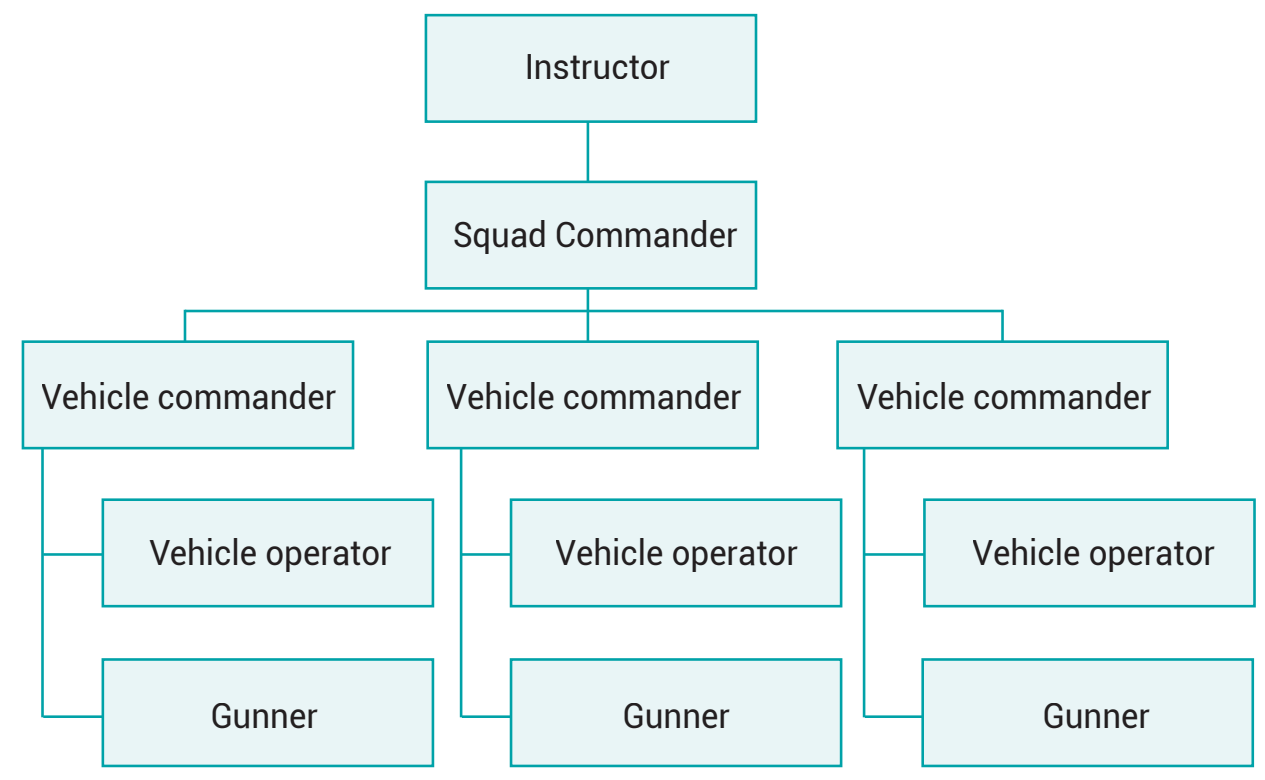

Figure 2. Organizational structure of Cavalry Units Source: own work

ARMA 3 is an open war simulation game, developed by Bohemia Interactive and distributed on the Steam platform. It was released on September 12, 2013 for Microsoft Windows. It allows participants (students) to face anything from individual infiltration missions to the coordination of group operations via multiplayer. Thus, it allows the choice of objectives, weaponry and tactical mission styles to be simulated.

\section{Description:}

Name: ARMA 3.

- Platform: PC.

- Available: digital download payware.

- Developer: Bohemia Interactive.

- Distributed: Bohemia Interactive.

- Genre: action, first person (FPS), tactical action (war).

- Players: 100, competitive and cooperative.

- Duration: Unlimited.

- Language: texts in Spanish and audio in English.

\section{Minimum requirements:}

- Operating system: Windows Vista SP2 / 7 SP1.

- $\quad$ Processor: Intel Dual-Core 2.4 GHz or AMD Dual-Core Athlon $2.5 \mathrm{GHz}$. 
- Memory: 2 GB RAM.

- Graphics card: NVIDIA GeForce 8800GT or AMD Radeon HD 3830 or Intel HD Graphics 4000 with 512 MB VRAM.

- DirectX: 10.

- Hard disk: 10 GB of free space.

- Sound: DirectX-compatible.

Recommended requirements:

- $\quad$ Operating system: Windows Vista SP2 or Windows 7 SP1

- $\quad$ Processor: Intel Core i5-2300 or AMD Phenom II X4 940 or higher

- Memory: 4 GB RAM

- Graphics card: NVIDIA GeForce GTX 560 or AMD Radeon HD 7750 with 1 GB VRAM or higher

- $\quad$ DirectX: 11

- Hard disk: 20 GB of free space

- Sound: DirectX-compatible

ARMA 3 allows the use of TrackIR (Head Tracking) and offers extraordinary realism within its scenarios. It also allows for extensive modification of the original simulator, providing new possibilities, settings, characters, dialogues, and objects, among others. Thus, it allows celestial navigation, visualization and interaction with the environment (animals, plants, among others), day and night simulation, expressing the fatigue of the soldier, just to name a few. In addition, it has various training scenarios, vehicle fleets -lightweight, medium and heavy-, infantry, artillery, aircraft, and drones, among others. The simulator also allows for the editing of vehicles and scenarios. Therefore, if the game does not have a vehicle, it is possible to design it. In relation to the scenarios, they can be designed to carry out terrestrial, aerial or fluvial operations, with the purpose of evaluating the Command capacity of the commanders, the maneuverability and operation of the personnel, for example carriers and gunners. 

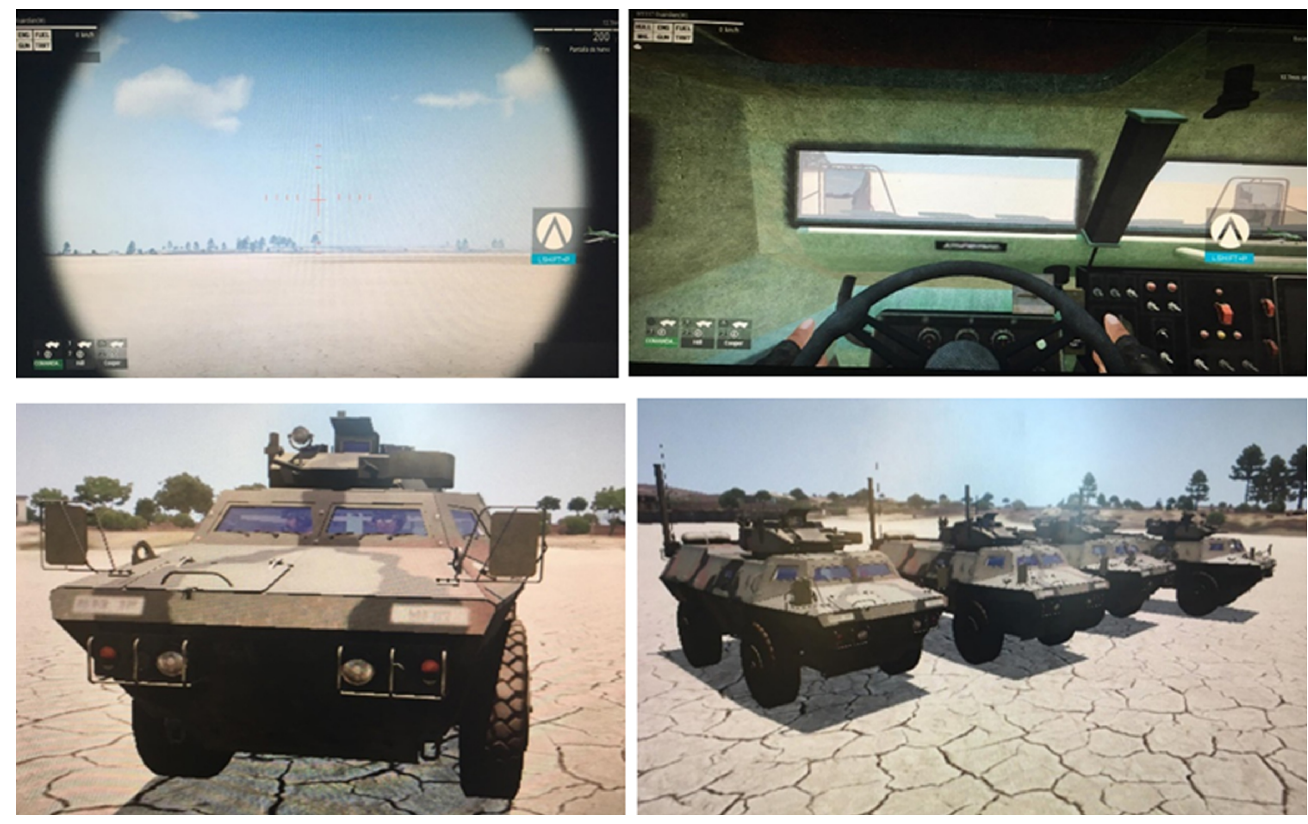

Figure 3. Virtual environment, implementing ARMA 3

Source: courtesy of the Cavalry School

The operations to be performed are the same as those carried out in a real training or combat mission, using orders through the system, but focused in a manner analogous to reality. The verification of the training is the responsibility of the Instructor who visualizes the whole operation through the main computer.
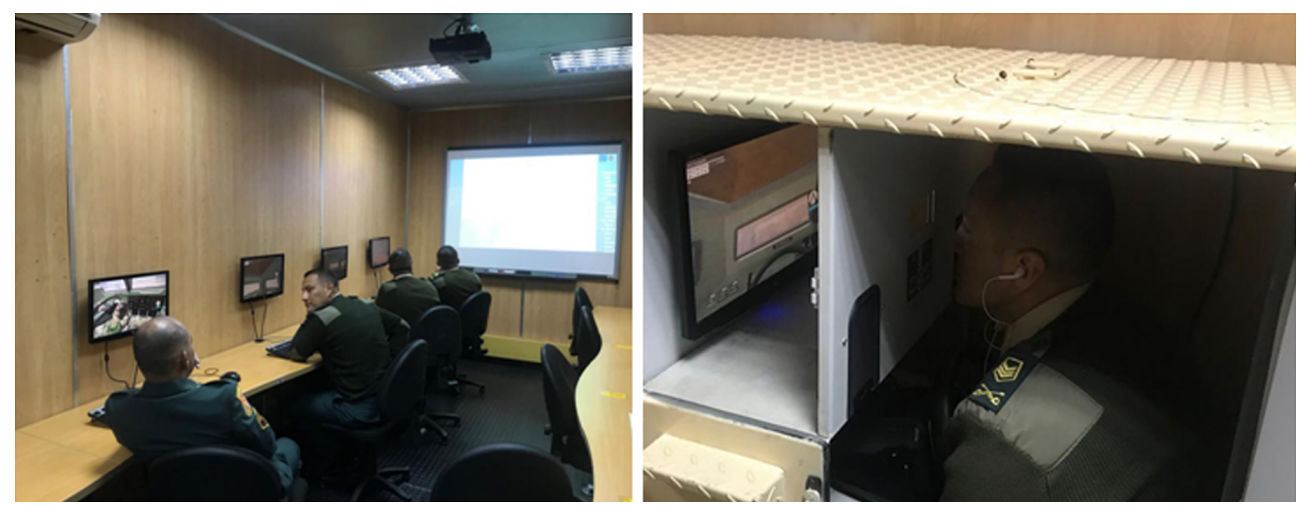

Figure 4. Students being trained in the Mobile Classroom, Courtesy of the ESCAB Cavalry School

Source: courtesy of the Cavalry School

This Mobile Classroom was validated by the doctrine instructors, deputy director and director of the Cavalry School, who detailed each one of the exercises, 
environments and roles involved in each practice and its closeness to those performed in the reality.

The training process and, in that sense, the stages of the present research process, are constituted by (i) the initial instruction, (ii) the diagnostic test, (iii) the feedback of the diagnosis, (iv) the performance test, and (v) performance evaluation. The cavalry soldier initiates his instruction in a theoretical way where he knows the functionality of the mobile classroom and the components and tools that he will use in the development of his training. An entry behavior or initial instruction is carried out, where the instructor evaluates the student in his role and in each of the other roles and, in particular, the NCO platoon commanders will also be evaluated as operators and gunners. Thus, the platoon commander has the wisdom to provide orders with the experience lived as the other roles. With the exercise completed, the cavalry soldier receives feedback from the instructor where, as a commander, they are shown their performance, consistency in their orders, decision-making opportunity, and agility in decision-making. On the other hand, as a crew member (operator, gunner) the attention, discipline, subordination, respect for the orders of his superior, maturity and experience in his military tactical formation, aim in the case of the gunner and expertise in the case of the operator are taken into account.

After this feedback, a second exercise is practiced where the performance of the crew is evaluated, applying the conditions already exposed in the feedback, where a disciplined crew, a serene squad commander, who is consistent under pressure, and makes clear and correct decisions on time, are obtained as the final product. Other obtained results are a vehicle commander who recommends his platoon commander, who listens to his crew and is subordinate to his commander; an operator and artillery crew that, due to the leadership of their commander, are disciplined and, above all, calm in their performance.

\section{RESULTS}

With the implementation of this Mobile Classroom, 13 students can be trained per session, having their profile defined within Cavalry Planning [1]. These are: 4 Vehicle Operators, 4 Gunners and 5 Team and Squad Commanders, performing all the tactical training within the simulation, where they are immersed in a simulated terrain. The operations to be performed are the same as those carried out under real instruction, using orders through the system, but focused in a manner analogous to reality. The verification and qualification of the training is in charge of the Instructor who visualizes the whole operation through the main computer, resulting in every 
trained man acquiring military competence in the tactical and technical doctrine, making correct decisions, identifying the military analysis of the terrain, development of war games and simulation of vehicles as force multipliers, taking the opportunity to perform more practical hours in operations and maneuvers. Therefore, an average of 898 trained students per year are reached in the courses run by the Cavalry School such as: Basic Cavalry weapons course, Tactics applied to armor, Advanced training for sergeants, Intermediate training course for non-commissioned officers, Specialization of the Weapon for Cadets, command course for Captains, Intermediate course for Lieutenants, and specialization for officers. With the implementation of the Mobile Classroom, the military tactical training in Cavalry Mission Planning, personnel showed an improvement in theoretical and practical training, creating in the student the skill to function in a virtual context [18]. It led to more operational practice time in such a way that in the field, the student has the ability to perform their tasks correctly, thereby acquiring skilled officers, non-commissioned officers and enlisted soldiers at the School. The instruction for the men of Cavalry was adjusted and, then, what was initially developed in a purely theoretical context, was transformed to a theoretical-practical approach, providing a virtual scenario suitable to develop relevant abilities in the students, which led to achieving the training objectives.

The Mobile Classroom, as a training tool to instruct personnel in military tactics, resulted in a reduction of costs related to weapons, fuel, equipment wear and aspects of sustainability of a real environment. With reference to the maneuver and simulation equipment installed in the Classroom, when considering preventive maintenance and equipment updates, the research team demonstrated that it was less expensive and more productive than a real scenario. Currently, the Classroom can be moved around the national territory according to the needs of each Unit or Battalion, avoiding the movement of personnel, reducing the cost of logistical operations in the Units established by the National Army according to their rotations and military projections.

In relation to the skills and abilities of personnel of all ranks, before instruction many were making impulsive decisions without foundation, lacking an understanding in their performance and intention. After receiving instruction, a commander is obtained who conceives the recommendation of a subordinate who fully complies with the intention of the commander. 


\section{DISCUSSION, CONCLUSIONS AND RECOMMENDATIONS}

At present it is possible to identify determining factors for the design and implementation of training strategies for military personnel. The complexity of armaments, the variety and complexity of the missions, the operational characteristics of missions in unknown territories, and the asymmetry of threats and conflicts are factors that demand the widening of military training strategies and the availability of simulation and training methodologies. These offer the possibility of experiencing simulated combat scenarios, with the possibilities of planning attack strategies, territorial analysis, war role play, vehicle simulation, and defining criteria for training improvement, among others. This allows for effective training and training processes, availability for more personnel, reduction of operating and maintenance costs, and greater sustainability.
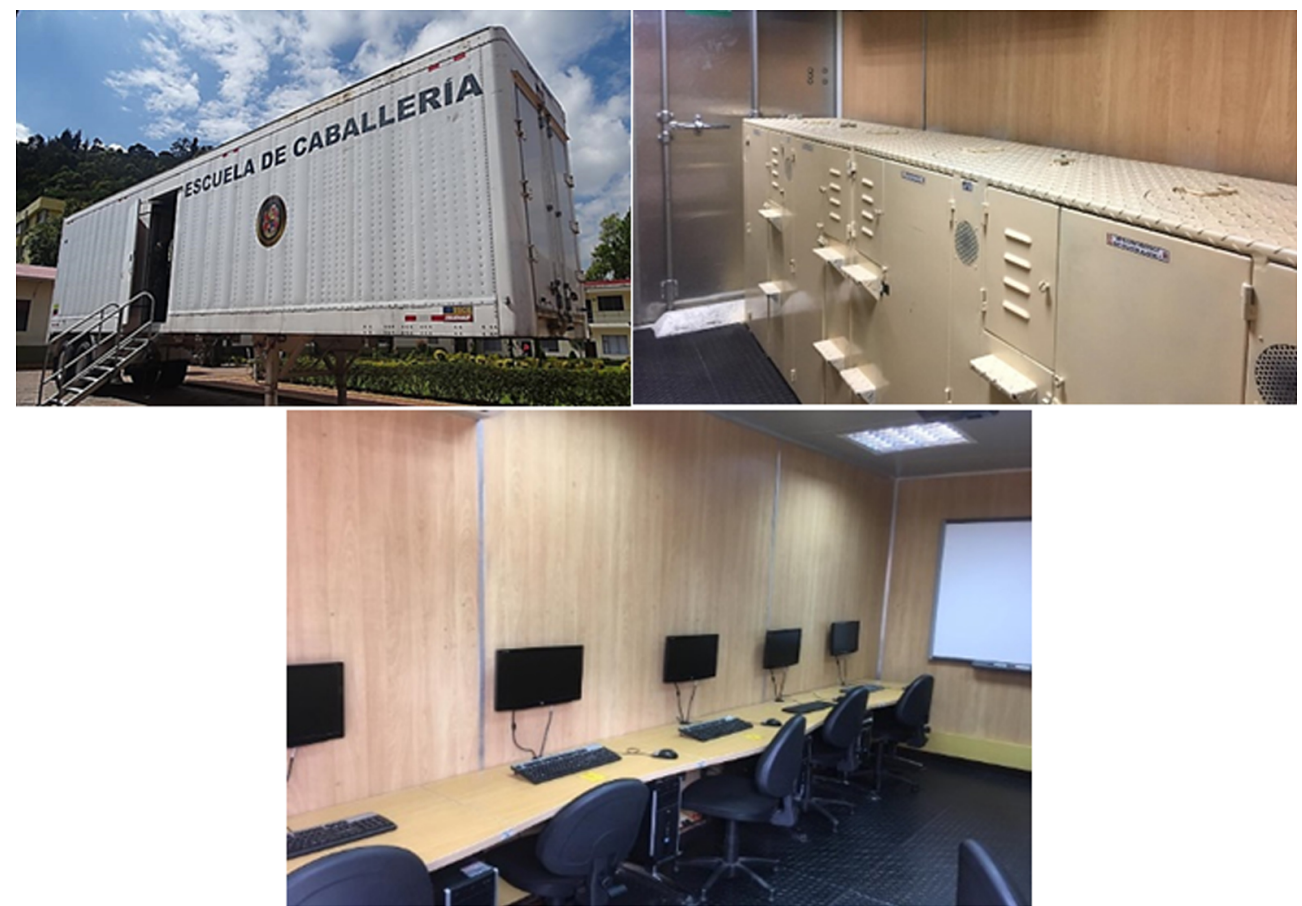

Figure 5. Trailer transformed into Mobile Classroom, Courtesy of ESCAB Cavalry School Source: courtesy of the Cavalry School

Taking into account the obtained results, the importance of new tools for military tactical training that allow the student of the Cavalry School to develop their skills and abilities is made evident. They will help in the effectiveness of military activities, integrating officers, non-commissioned officers and enlisted soldiers, making them 
more aware of the issues related to the mission and providing insight into the different roles of the crew.

The implementation of simulation systems allows students to contemplate different scenarios in which they can be involved and maneuver the necessary equipment in each operation, such as: command and control, shooting, and driving vehicles. In this way, similar sensations to the real ones are produced, which allows for the development of a better training, creating focus, criterion, skill and the technical competence required to perform with success and efficiency at the moment of the real event.

With the use of the Mobile Classrooms, the training imparted becomes dynamic and pertinent to the weapon's needs. This causes students to take a greater interest in learning and, therefore, be participatory in the virtual learning environment, achieving better levels of training accordingly to the doctrine taught by the instructor. Although a real scenario could provide better performance for training, the use of the mobile classroom with the simulation provides the student with more hours of practice, being trained with focus and discipline at a lower cost of sustainability in all aspects involved in the training.

From this research process, it is possible to affirm that the implementation of the mobile classroom and the simulation system contributes to the development of skills and abilities required for the members of the cavalry. It improves the capacities for decision making, increases the perceptive variation, and improves coordination, communication and team decision making. An educational environment of this nature and characteristics allows the student to get involved without risk to themselves or their equipment. Finally, the implemented strategy allows the evaluation of skills and abilities and allows the student access to constant training and update tools.

From the collected data, its analysis and the derived conclusions, it is possible to identify two different recommendations. First, the challenges of taking advantage of technological developments in the teaching and learning processes. Secondly, the need for constant updating of training processes that use technical and technological developments. With respect to the first recommendation, it is necessary that the industry of simulation software and video games development is aware of the needs of the market. According to Ruiz [19], it is necessary to transverse the perspective of engineering in professional training programs in computer science, leading to the strengthening of the supply of Software Engineering programs. This, according to his proposal, and adjusted to the definition of IEEE [20], is "[...] a special type of engineering, traditionally framed within the field of knowledge called Computing" [19]. In this same line, Camilloni and Vallespir [21], who define in the terms of the IEEE [20] Software 
Engineering, recognize the importance that software has taken in ordinary life, including educational processes; This results in a significant demand from engineering professionals in this field to respond to the problems of time, cost and quality of computer products. In Latin America, García, Pacheco and Coronel [22] acknowledge that an advance of software in education, research and development is now evident. However, these advances are presented separately. This results in large training investments by the company, given the limited professional training in higher education institutions. Accordingly, Engineering itself, as a discipline, has been adopting teaching models adjusted to the developments of Software Engineering. Several studies give account of it [22] [23] [24] [25] [25] [26] and conclude the importance of training in Software Engineering; and also, the importance of the incorporation of technological developments in vocational training processes in different fields [27] and, finally, in the importance of simulation as a professional training strategy.

Secondly, it is necessary to take into account the importance of updating this significant resource of training and restraint by implementing intercommunication systems that allow for the individual interaction between crews and commanders, to be more realistic in the fulfillment of each mission; a system of video cameras that show the relationship of the crew in events under pressure and thus be able to, firsthand, establish a profile for each man. It is important to individualize the position of the vehicle commanders since the four people are in a single cubicle and it generates distraction. The planning is done with the commanders, individual tasks are imposed for each of the vehicle and each vehicle commander does their own task according to the intention of the platoon commander.

Finally, this process should open new research fields around the analysis of the capacity of the technology to, each time, do more with less, maximize the results -in this case, the development of competence and skills in the military personnel of the Cavalry School- with less risk and investment in infrastructure, and greater economic, temporal and spatial sustainability. Therefore, the use of computer technologies, the development of technologies with internet support, virtualization and technological advances, should contribute to develop and consolidate more efficient teaching and learning processes of techniques, technologies and sciences.

The School of Cavalry with the implementation of the Mobile Classroom to Military Tactical Training in Cavalry Missions Planning bases its importance and applicability on two main arguments;

Economic resource: Safeguard the budget assigned to the force, since it allows the institution to train and retrain the staff, optimizing public resources, without using vehicles, ammunition and suffering technical equipment wear. 
Preservation of human resources: The mitigation of the accident risk in the development of tactical training exercises, avoiding the generation of compensation for possible accidents.

Therefore, this classroom or type of training allows the institution to comply with the institutional mission in preserving the public resource and protecting the physical integrity of the officers, non-commissioned officers and enlisted soldiers, thereby fully complying with the constitutional mandate, "The Nation will have for its defense a Permanent Military Force constituted by the Army, the Navy and the Air Force ... The Military Forces will have as primary purpose the defense of the sovereignty, the independence, the integrity of the national territory and the constitutional order ..."

\section{Referencias}

[1] Fuerzas Militares de Colombia. Ejército Nacional, "Manual EJC.3-164," Manual de Operaciones Grupo Caballeria. Bogotá, Colombia: Editorial Sección Publicaciones Ejército, 2007, p. 267.

[2] Fuerzas Militares de Colombia. Ejército Nacional, "Manual EJC. 3-226," Manual Empleo Táctico del Pelotón Mecanizado Mediano en Operaciones Irregulares. Bogotá, Colombia: Editorial Sección Publicaciones Ejército, 2010, p. 120

[3] I. V. Márquez, "La simulación como aprendizaje: educación y mundos virtuales," I/ Congreso Internacional Comunicación 3.0. Madrid, 2010, p. 57-63

[4] A. García Carbonell y F. Watts Hooge, "Perspectiva histórica de simulación y juego como estrategia docente: de la guerra al aula de lenguas para fines específicos," Ibérica: Revista de la Asociación Europea de Lenguas para Fines Específicos, no. 13, pp. 65-84, 2007.

[5] ARMA 3, Bohemia Interactive, 2019. [On line]. Available: https://arma3.com/. p. 1

[6] M. Coman, G. Bârsan and D. Badea, "Using Project-based Management to Analyse the Modernization Opportunity for Military Infrastructure Regarding Simulation Training," Revista Academiei Fortelor Terestre, vol. 21, no. 2, pp. 161-169, 2016.

[7] P. A. Guze, "Using Technology to Meet the Challenges of Medical Education," Transactions of the American Clinical and Climatological Association, vol. 126, pp. 260-270, 2015.

[8] J. Birt, E. Moore and M. Cowling, "Improving paramedic distance education through mobile mixed reality simulation," Australasian Journal of Educational Technology, vol. 33, no. 6, pp. 69-83, 2017. 
[9] S. Nitschke, "Novedades sobre entrenamiento y simulación para vehículos terrestres y navales," Tecnología Militar - TECMIL, no. 4, pp. 42-45, 2014.

[10] “MASA: El COTER emplea el sistema de simulación COMBATER”, Tecnología Militar - TECMIL, no. 1, pp. 53-54, 2019.

[11] E. O. Bratt, "Intelligent Tutoring for Ill-Defined Domains in Military Simulation-Based Training," International Journal of Artificial Intelligence in Education, vol. 19, no. 4, pp. 337-356, 2009.

[12] K.-H. Chang, Y.-C. Chang and H.-Y. Chung, "A Novel AHP-Based Benefit Evaluation Model of Military Simulation Training Systems," Mathematical Problems in Engineering, vol. 2015, pp. 1-14, 2015.

[13] D. L. Riddle, R. J. Chapman, W. Y. Pike and J. Norfleet, "MST-READI: Practical Guidance for Military Medical Simulation Training Evaluation Research," Journal of Interactive Instruction Development, vol. 20, no. 4, pp. 21-26, 2009.

[14] D. N. Naumann, D. M. Bowley, M. J. Midwinter, A. WalkerandI. Pallister, "High-Fidelity Simulation Model of Pelvic Hemorrhagic Trauma: The Future for Military Surgical Skills Training?," Military Medicine, vol. 181, no. 11, pp. 1407-1409, 2016.

[15] D. Cosma and M.-P. Stanic, "Implementing a Software Modeling -Simulation in Military Training," Revista Academiei Fortelor Terestre, vol. 16, no. 2, pp. 204-2015, 2011.

[16] C. Goolsby and S. Deering, "Hybrid Simulation During Military Medical Student Field Training-A Novel Curriculum,” Military Medicine, vol. 178, no. 7, pp. 742-745, 2013.

[17] G. S. Taylor and J. S. Barnett, "Evaluation of Wearable Simulation Interface for Military Training," Human Factors, vol. 55, no. 3, pp. 672-690, 2013.

[18] B. Marcano, "Juegos serios y entrenamiento en la sociedad digital," Revista Electrónica Teoría de la Educación. Educación y Cultura en la Sociedad de la Información, vol. 9, no. 3, pp. 93-107, 2008.

[19] F. Ruíz, "La Enseñanza de la Ingeniería del Software en el marco del Espacio Europeo de Educación Superior," II Simposio Nacional de Docencia en la Informática (SINDI'2007) y II Congreso Español de Informática (CEDI). Zaragoza, 2007. p.1

[20] IEEE, Std 610.12-1990. Ney York: Institute of Electrical and Electronics Engineers, 1990. pp. $15-30$ 
[21] L. Cami-Iloni y D. Vallespir, Educación en Ingeniería de Software. Montevideo: Universidad de la República, 2015, p. 10

[22] I. García, C. Pacheco y N. Coronel, "Aprender a través de la Práctica: Definiendo un Modelo Alternativo para la Educación de la Ingeniería de Software en las UniversidadesMexicanas como medio para reducir el vacío entre la Industria y la Academia," Coloquio Nacional de Investigación en Ingeniería de Software y Vinculación Academia-Industria. León, 2010. pp. 1236-145

[23] A. P. Lorandi-Medina, G. Hermida-Saba, J. Hernández-Silva y E. Ladrón de Guevara Durán, "Los Laboratorios Virtuales y Laboratorios Remotos en la Enseñanza de la Ingeniería," Revista Internacional de Educación en Ingeniería, vol. 4, pp. 24-30, 2011.

[24] G. Martín-Lorenzo, J. P. Suárez-Rivero y M. García-Domínguez, Desarrollo de un Laboratorio Virtual para el Estudio y Simulación de Mecanismos en la Ingeniería. Las Palmas de Gran Canaria: Universidad de Las Palmas de Gran Canaria, 2003. pp. 10-15

[25] J. Muñoz-García, M. C. Alfaro-Rodríguez y C. Cabeza-Fernánez, "Aplicaciones de la simulación de reactores en enseñanza de la ingeniería de la reacción química," Revista de Enseñanza Universitaria, vol. ext., pp. 127-138, 2000.

[26] D. Rodriguez, M. Daniel y R. Carlos, "Uso de software de simulación en la enseñanza de la Física. Una aplicación en la carrera de Ingeniería Quimica," Tecnología, Ciencia, Educación, vol. 24, no. 2, pp. 127-136, 2009.

[27] A. G. Piscitelli-Altomari, "Realidad virtual y realidad aumentada en la educación, una instantánea nacional e internacional," Economía Creativa, no. 7, pp. 34-65, 2017.

[28] L. A. Douglas-Costucica y M. Ramallo, "Los juegos de simulación como método educativo para el aprendizaje en carreras de ingeniería," Atlante. Cuadernos de Educación y Desarrollo, vol. seg. época, pp. 1-12, junio 2014. 